\title{
Pituitary-gonadal axis in sterile male mice heterozygous for autosomal reciprocal translocation $\mathrm{T} 145 \mathrm{H}$
}

\author{
Nicole Fellmann, M. André, J. F. Jarrige and D. Boucher \\ Laboratoire de Physiologie, Faculté de Médecine, Place Henri Dunant, 63000 Clermont-Ferrand, \\ France
}

\begin{abstract}
Summary. Male mice heterozygous for the reciprocal autosomal translocation $\mathrm{T}(7,19) 145 \mathrm{H}(\mathrm{T} 145 \mathrm{H} /+)$ were completely sterile. Spermatogenesis was arrested at some stage during the first meiotic division. The pituitary-gonadal axes of these mice were compared with those of normal male littermates $(+/+)$ at 63 days of age. Testis and epididymis weights were significantly lower than in normal males, but no deficiencies in circulating FSH were observed despite drastic loss of germinal cells, suggesting that spermatids were not involved in the feed-back control of FSH $(\mathrm{T} 145 \mathrm{H} /+, 2155 \pm 64 \mathrm{ng} / \mathrm{ml} ;+/+, 1830 \pm 94 \mathrm{ng} / \mathrm{ml}$; mean \pm s.e.m.). Androgen activity in $\mathrm{T} 145 \mathrm{H} /+$ males seemed normal judging by weights of androgen target tissues (prostate, seminal vesicles), serum $\mathrm{LH}$ and testosterone levels $(\mathrm{T} 145 \mathrm{H} /+: \mathrm{LH}$ $=132 \pm 18 \mathrm{ng} / \mathrm{ml}$, testosterone $=5.5 \pm 2.8 \mathrm{ng} / \mathrm{ml} ;+/+: \mathrm{LH}=127 \pm 22 \mathrm{ng} / \mathrm{ml}$, testosterone $=7.4 \pm 2.7 \mathrm{ng} / \mathrm{ml}$ ). These results indicate that the translocation in the heterozygous state does not modify control of FSH secretion or the LH-interstitial cell axis.
\end{abstract}

\section{Introduction}

The infertility of males heterozygous for autosomal translocations has been established in men since 1964 (Kjessler, 1964; McIlree et al., 1966). Kjessler (1972) showed that reciprocal autosomal translocation was a cause of infertility among $15 \%$ of sterile men bearing chromosomal abnormalities. These translocation carriers were oligospermic or azoospermic. Among patients showing drastic spermatogenesis damage, plasma gonadotrophin levels were surprisingly normal, unlike those in patients with sex chromosomal disorders (Millet, Plachot, Lety, de Grouchy \& Netter, 1975).

An animal with similar chromosomal abnormalities should enable examination of hormonal aspects and their controls. Lyon \& Meredith (1966) described full sterility of male laboratory mice heterozygous for the reciprocal autosomal translocation $\mathrm{T}(7 ; 19) 145 \mathrm{H}$. The impairment of male fertility was a consequence of breakdown of spermatogenic differentiation, resulting in the complete absence of spermatozoa. In the present study we compared the pituitary-gonadal axis of these sterile mice $(\mathrm{T} 145 \mathrm{H} /+)$ with that of their normal littermates $(+/+)$ at adulthood. As far as we know, this is the first time that such a study has been carried out.

\section{Materials and Methods}

Animals. The translocation $\mathrm{T} 145 \mathrm{H}$ in the heterozygous state caused only 'semi-sterility' in females. It was therefore possible to obtain the sterile male mice $(\mathrm{T} 145 \mathrm{H} /+)$ from crosses of normal males, 
$\operatorname{NMRI}(+/+)$, with females heterozygous for the translocation T145H. Hypogonadal males could not be distinguished from their normal male littermates by external examination: the failure of spermatogenesis was estimated only when the mice were killed from the absence of spermatozoa in the caput epididymidis. Randomly sterile mice and their normal littermates were born and housed in translucent plastic cages. Food and water were always available. The temperature in the animal room was stable at $22^{\circ} \mathrm{C}$ and there was continuous ventilation. Lighting was set to a $12 \mathrm{~h}$ light:12 h dark cycle with lights on at $07: 00 \mathrm{~h}$. The mice were weaned at 21 days of age and only males were kept.

The mice were weighed every week, for 9 weeks. At 63 days of age, the animals were weighed and then killed by decapitation after light ether anaesthesia. They were routinely killed between 09:00 and 11:00 $\mathrm{h}$ to minimize variations due to circadian rhythmicity.

Serum preparation. Trunk blood was collected over tubes without any anticoagulant drug, and centrifuged. The serum was stored at $-20^{\circ} \mathrm{C}$ until assay.

Sperm count. The degree of spermatogenic failure was estimated from the number of spermatozoa in each caput epididymidis by the method of Searle \& Beechey (1974). Each caput epididymidis was carefully separated from the testis and surrounding fat. It was cut through the vasa efferentia on one side and its junction with the corpus epididymidis on the other side. The epididymis was removed and macerated in a watchglass in $1 \mathrm{ml}$ of a $1 \%$ solution of trisodium citrate. It was well mixed by stripping with forceps. Any large lumps were allowed to settle for $1 \mathrm{~min}$ at ambient temperature. The number of suspended spermatozoa was determined in a haemocytometer chamber through a light microscope.

Organ weights. The prostate, seminal vesicles, epididymides, testes and adrenal glands were quickly removed and weighed to the nearest $0.1 \mathrm{mg}$.

Histological procedure. Right testes were fixed in Zenker formol and embedded in Paraplast. Sections (7.5 $\mu \mathrm{m}$ thick) were cut and stained with haematoxylin and eosin for qualitative evaluation.

Serum hormones. Testosterone concentrations were determined by radioimmunoassay. This assay used a specific antiserum raised against serum testosterone-11-hemisuccinate-bovine serum albumin and cross-reacted with dihydrotestosterone $(57 \%)$. Serum samples $(50 \mu \mathrm{l})$ were extracted with ether. The extracts were assayed after celite chromatography to avoid cross-reaction with dihydrotestosterone (Thorneycroft, Ribeiro \& Stone, 1973). Estimation of testosterone in diluted serum from a pool containing a high concentration of this steroid gave a dose-response curve parallel to that of standards. The sensitivity of the assay was $10 \mathrm{pg}$ and the coefficient of variation of replicate analyses was $10 \%$. Recovery of carrier testosterone from pooled serum was $75 \%$.

Serum LH and FSH concentrations were measured by double-antibody radioimmunoassay systems (André, Boucher \& Thieblot, 1976). These assays utilized Rat-RIA reagents supplied by the NIAMDD. For LH, the antiserum was NIAMDD-rat-LH-S5, the hormone for iodination was NIAMDD-rat-LH-I5 and the hormone reference preparation NIAMDD-rat-LH-RP-1. For FSH, the antiserum was NIAMDD-rat-FSH S10, the hormone for iodination was NIAMDD-rat-FSH-I4 and the hormone reference preparation NIAMDD-rat-FSH-RP-1.

In a preliminary study, validity of the LH and FSH rat assays was tested on pooled sera of 10 intact male NMRI mice, 7 weeks old, and 10 male NMRI mice that had been bilaterally castrated 2 days earlier. The slopes of the standard curves and serum dilution curves were calculated from the $\log$-logit transformation by the least squares method and were tested for parallelism by covariance analysis. The parameters of the curves for LH and FSH were respectively: standard curve, $y=$ $-2.25 \log$ LH RP-1 ng +2.70 and $-2.31 \log$ FSH RP-1 ng +4.62 ; normal mouse serum, $y=$ $-2.20 \log \mu \mathrm{l}$ serum +5.50 and $-2.61 \log \mu \mathrm{l}$ serum +5.02 ; castrated mouse serum, $y=-1.90$ $\log \mu \mathrm{l}$ serum +3.43 and $-2 \cdot 30 \log \mu \mathrm{l}$ serum $+3 \cdot 65$. No significant departure from parallelism within standard curves and serum dilution curves was observed for $\mathrm{LH}$ or FSH. Serum levels of LH and FSH in pools gave a B/Bo intercept of 0.5 : in intact mice the $\mathrm{LH}$ value was $49 \mathrm{ng} \mathrm{LH} \mathrm{RP}-1 / \mathrm{ml}$ and FSH $1201 \mathrm{ng}$ FSH RP-1/ml; in castrated mice, LH was $227 \mathrm{ng} \mathrm{LH} \mathrm{RP-1/ml} \mathrm{and} \mathrm{FSH} 2651 \mathrm{ng}$ 


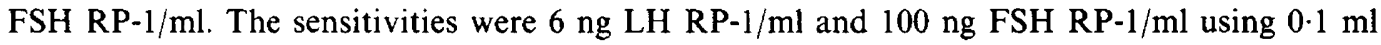
aliquots of serum. Intra-assay accuracies (mean \pm s.d.) were $3 \cdot 5 \pm 2 \cdot 4 \%$ for LH and $3 \cdot 3 \pm 2 \cdot 3 \%$ for FSH.

Statistical analysis. Student's $t$ test was used to compare the means, and differences were considered to be significant if $P \leqslant 0.05$.

\section{Results}

Results of the crossing. Of the 12 crosses between 5 females $(\mathrm{T} 145 \mathrm{H} /+)$ and 12 males $(+/+), 26$ females and 36 males were obtained. The sperm count in the caput epididymidis revealed that 17 of the 36 male offspring $(47.2 \%)$ were azoospermic. When we compared the fertility of the 5 heterozygous females used for the crosses with that of 19 normal females (NMRI $(+/+)$ ), the mean litter size of the former $(5 \cdot 17)$ was about $57 \%$ of that of the latter $(9 \cdot 05)$.

Organ and body weights. We observed no apparent diffference in body growth between 21 and 63 days of age among $+/+$ and $\mathrm{T} 145 \mathrm{H} /+$ males from the same litter and randomly bred in the same cage. By 63 days of age, body weights were similar in the 2 groups of animals (Table 1).

Table 1. Body and organ weights (mean \pm s.e.m.) in 63-day-old normal and azoospermic males

\begin{tabular}{lcc}
\hline & Normal males & Azoospermic males \\
\hline No. of males & 19 & 17 \\
Body weight (g) & $31 \cdot 1 \pm 0 \cdot 6$ & $31 \cdot 9 \pm 0 \cdot 5$ \\
Wt of right testis (mg) & $102 \cdot 7 \pm 3 \cdot 1$ & $34 \cdot 9 \pm 1 \cdot 7^{*}$ \\
Wt of epididymis (mg) & $30 \cdot 3 \pm 0 \cdot 7$ & $19 \cdot 8 \pm 0 \cdot 6^{*}$ \\
Wt of prostate gland (mg) & $10 \cdot 4 \pm 0 \cdot 6$ & $9 \cdot 8 \pm 0 \cdot 8$ \\
Wt of seminal vesicle glands (mg) & $216 \cdot 5 \pm 11 \cdot 9$ & $222.0 \pm 11 \cdot 0$ \\
Wt of adrenal glands (mg) & & \\
$\quad$ Right & $2 \cdot 2 \pm 0 \cdot 1$ & $2 \cdot 2 \pm 0 \cdot 1$ \\
$\quad$ Left & $2 \cdot 2 \pm 0 \cdot 1$ & $2 \cdot 2 \pm 0 \cdot 1$ \\
\hline
\end{tabular}

* $P<0.001$ compared with value for normal males.

Testis and epididymis weights from $\mathrm{T} 145 \mathrm{H} /+$ animals were significantly lower than those for $+1+$ males, but the weights of the prostate, seminal vesicles and adrenal glands were similar in the 2 groups of animals (Table 1).

Testicular histology. Histological examination of $\mathrm{T} 145 \mathrm{H} /+$ testis (Pl. 1, Fig. 2) revealed that seminiferous tubule size was reduced. Every stage from spermatogonia to primary spermatocytes was present, but from the spermatocyte stage onwards, very few cells could be seen, indicating that spermatogenesis had been arrested at some stage during meiosis. No spermatocytes II were observed (see Pl. 1, Fig. 2).

Serum testosterone levels. Serum samples from 2 or more mice of each genotype were pooled to obtain a sufficient volume for testosterone determination, no significant difference in circulating testosterone concentrations was present between $+/+$ and $\mathrm{T} 145 \mathrm{H} /+$ males (Text-fig. 1a).

Serum $L H$ and FSH levels. There were no significant differences between $+/+$ and $\mathrm{T} 145 \mathrm{H} /+$ male mice for serum FSH (Text-fig. 1b) and LH (Text-fig. 1c) concentrations at 63 days of age. 



Text-fig. 1. Serum concentrations of (a) testosterone, (b) FSH and (c) LH in normal (N) and azoospermic (A) male mice, 63 days of age. Each point in (a) represents a determination for a pool of 2 or 3 mice. Horizontal lines indicate the mean value \pm s.e.m.

\section{Discussion}

The present study shows that the relative fertility of heterozygous females for the reciprocal autosomal translocation $\mathrm{T} 145 \mathrm{H}$ is reduced. The mean litter size of $\mathrm{T} 145 \mathrm{H} /+$ females mated to $+1+$ males was about $57 \%$ of that of normals. These results agree with those of Lyon \& Meredith (1966), who found $52 \%$ from the same crossing. These authors showed a normal 1:1 segregation among their progeny of translocation heterozygotes and normals with respect to wild type. In our study, $47.2 \%$ of the progeny were sterile. Hence there is no reason to suspect reduced viability of the translocation carriers as suggested by Lyon \& Meredith (1966).

The sterile male mice were phenotypically normal. They could only be distinguished from the $+1+$ males when killed: as in previous reports (Lyon \& Meredith, 1966; Forejt \& Gregorová, 1977), males were classified as sterile or normal on the basis of testis weight and the complete lack of spermatozoa in the epididymides. Testes of adult $\mathrm{T} 145 \mathrm{H} /+$ mice weighed one third those of normal mice. Our data are in agreement with those of Forejt \& Gregorova (1977: weights of paired testes of $\mathrm{T} 145 \mathrm{H} /+$ and $+/+$ males $68.2 \mathrm{mg}$ and $206.8 \mathrm{mg}$, respectively).

Various reports have provided data supporting the role of testosterone, LH and FSH in the process of spermatogenesis but their relative importance has not yet been established. Reciprocally, we have attempted in the present study to determine whether the defects in spermatogenesis modify gonadotrophin and/or steroid secretions. Our results raise the issue of FSH secretion control. The postulate that the seminiferous tubule produces a chemical substance called 'inhibin' (McCullagh, 1932) that inhibits FSH secretion is now widely accepted. Sertoli cells are the probable site of its synthesis (Steinberger \& Steinberger, 1976), either alone (Means, 1974; Musto, Santen, Huckins \& Bardin, 1978) or in association with germinal cells (the spermatids) suggested by observations on men (Johnsen, 1970; Rosen \& Weintraub, 1971; Franchimont, Chari, Schellen \& 



Fig. 1. Testis of a normal $(+/+)$ male mouse at 63 days of age. $\times 500$.

Fig. 2. Testis of a sterile male $(\mathrm{T} 145 \mathrm{H} /+)$ at 63 days of age, showing that spermatogenesis has been arrested between spermatocyte I and II stages. $\times 500$. 
Demoulin, 1975) and other animals (Debeljuk, Arimura \& Schally, 1973; Hopkinson, Dulisch, Gauss, Hilscher \& Hirschhäuser, 1978; Sheth, Dandekar \& Seethalakshmi, 1981)

In the present study, serum FSH level was normal while gametogenesis was arrested before the spermatid stage. These results indicate that spermatids are not necessary for the production of an amount of inhibin sufficient to affect FSH values. A similar conclusion was tentatively drawn from observations on men that had no spermatids and normal FSH plasma levels (Baker et at., 1976); these investigators showed that spermatogonial numbers remained inversely correlated with FSH levels. This has also been confirmed by studies indicating normal FSH secretion in rats with germ cell depletion without reduction in spermatogonial numbers resulting from vitamin A deficiency (Krueger, Hodgen \& Sherins, 1974) or hydroxyurea treatment (Mecklenburg, Hetzel, Gulyas \& Lipsett, 1975). Reciprocally, the level of FSH was considerably elevated in genetic mutant mice (called Steel) exhibiting morphologically normal Sertoli cells and complete absence of any spermatogenic cells including immature spermatogonia (Younglai \& Chui, 1973). However, in a number of patients with virtually normal spermatogonial complements, FSH levels were elevated (Baker et al., 1976). The feed-back signal for FSH seems to depend on factors other than the absolute number of spermatogonia.

Androgen activity in our sterile mice, assessed from the weights of prostate and seminal vesicles and serum levels of testosterone and $\mathbf{L H}$, appeared normal. Under other germinal depletion conditions, the effects on the LH-Leydig cell axis were variable. No deficiencies in circulating LH and testosterone have been reported for an azoospermic line of rats (BIL/1 strain) (Greiner, Gill, Kunz \& Gay, 1980). In rats treated with busulfan, the LH values were elevated in one study (Debeljuk et al., 1973) but not in another (Gomes, Hall, Jain \& Boot, 1973). In sterile Steel mice, high LH concentration was associated with normal testosterone values (Younglai \& Chui, 1973). Some investigators have reported normal plasma LH and testosterone concentration in infertile men with autosomal translocations (Millet et al., 1975) and in most patients with germinal cell arrest (de Kretser et al., 1972; Franchimont et al., 1975; Baker et al., 1976; Boucher, Hermabessière, Grizard, Doly \& Bruhat, 1977). Elevated serum levels of LH associated with reduced testosterone concentrations were found only in patients with severe loss of germinal cells, especially with sex chromosomal disorders.

In the present study, there was a wide variation in circulating testosterone concentration $(0 \cdot 9-$ $24.5 \mathrm{ng} / \mathrm{ml}$ ) in individual pairs of mice and this could be accounted for by the episodic secretion of LH and testosterone that is known to occur in normal mice (Bartke \& Dalterio, 1975; Barkley \& Goldman, 1977). The apparent preponderance of interstitial cells in $\mathrm{T} 145 \mathrm{H} /+$ males was possibly illusory due to shrinkage of the seminiferous tubules and decrease in testicular size, because Lyon \& Meredith (1966) described "normal interstitial cells" in histological sections of testes from mice of the same translocation carrier type.

In conclusion, the present study has demonstrated that the reciprocal autosomal translocation $\mathrm{T} 145 \mathrm{H}$ in the heterozygote state in mice seemed to modify neither the control feed-back of FSH secretion nor the LH-interstitial cell axis. We suggest that spermatogenesis stages beyond spermatocyte I are not necessary to provide a normal circulating FSH concentration.

The female $\mathrm{T} 145 \mathrm{H} /+$ mice were obtained from the M.R.C. Radiobiological Research Unit, Harwell, Berkshire through the courtesy of Dr M. F. Lyon. We thank Mrs Christine Artonne, Mrs Dominique Cheyvialle and Mr Michel Delaitre for their skilful technical assistance.

\section{References}

André, M., Boucher, D. \& Thieblot, L. (1976) Conditions et limites au dosage radioimmunologique de la $\mathbf{L H}$ serique de rats normaux, hypophysectomisés ou castrés. C. r. Séanc. Soc. Biol. 170, 353-361.
Baker, H.W., Bremner, W.J., Burger, H.G., de Kretser, D.M., Dulmanis, A., Eddie, L.W., Hudson, B., Keogh, E.J., Lee, V.W.K. \& Rennie, G.C. (1976) Testicular control of follicle-stimulating hormone secretion. Recent Prog. Horm. Res. 32, 429-476. 
Barkley, M.S. \& Goldman, B.D. (1977) A quantitative study of serum testosterone, sex accessory organ growth, and the development of intermale aggression in the mouse. Horm. \& Behav. 8, 208-218.

Bartke, A. \& Dalterio, S. (1975) Evidence for episodic secretion of testosterone in laboratory mice. Steroids 26, 749-756.

Boucher, D., Hermabessière, J., Grizard, G., Doly, M. \& Bruhat, M. (1977) Exploration dynamique des gonado-stimulines et de la prolactine chez l'homme stérile. Test LHRH + TRH. Rev. franç. Gynéc. 72, $631-644$.

Debeljuk, L., Arimura, A. \& Schally, A.V. (1973) Pituitary and serum FSH and LH levels after massive and selective depletion of the germinal epithelium in the rat testis. Endocrinology 92, 48-54.

de Kretser, D.M., Burger, H.G., Fortune, D., Hudson, B., Long, A.R., Paulsen, C.A. \& Taft, H.P. (1972) Hormonal, histological and chromosomal studies in adult males with testicular disorders. J. clin. Endocr. Metab. 35, 392-401.

Forejt, J. \& Gregorová, S. (1977) Meiotic studies of translocations causing male sterility in the mouse. I. Autosomal reciprocal translocations. Cytogenet. Cell Genet. 19, 159-179.

Franchimont, P., Chari, S., Schellen, A.M. \& Demoulin, A. (1975) Relationship between gonadotrophins, spermatogenesis and seminal plasma. J. Steroid Biochem. 6, 1037-1042.

Gomes, W.R., Hall, R.W., Jain, S.K. \& Boot, L.R. (1973) Serum gonadotropin and testosterone levels during loss and recovery of spermatogenesis in rats. Endocrinology 93, 800-809.

Greiner, D.L., Gill, T.J., III, Kunz, H.W. \& Gay, V.L. (1980) Reproductive endocrine profile of a strain of rats which exhibits aspermatogenesis and reduced growth. Biol. Reprod. 23, 564-569.

Hopkinson, C.R.N., Dulisch, B., Gauss, G., Hilscher, W. \& Hirschhäuser, C. (1978) The effect of local testicular irradiation on testicular histology and plasma hormone levels in the male rat. Acta endocr., Copenh. 87, $413-423$.

Johnsen, S.G. (1970) The stage of spermatogenesis involved in the testicular hypophyseal feed-back mechanism in man. Acta endocr., Copenh. 64, 193210.

Kjessler, B. (1964) Meiosis in a man with a $D / D$ translocation and clinical sterility. Lancet 1, 1421-1423.

Kjessler, B. (1972) Facteurs génétiques dans la subfertilité mâle humaine. In Fécondité et Stérilité du Mâle, pp. 205-225. Masson et Cie., Paris.
Krueger, P.M., Hogden, G.D. \& Sherins, R.J. (1974) New evidence for the role of the Sertoli cell and spermatogonia in feed-back control of FSH secretion in male rats. Endocrinology $95,955-962$

Lyon, M. F. \& Meredith, R. (1966) Autosomal translocation causing male sterility and viable aneuploidy in the mouse. Cytogenetics 5, 335-354.

McCullagh, D.R. (1932) Dual endocrine activity of testes. Science, N.Y. 76, 19-20.

McIlree, M.E., Price, W.H., Court-Brown, W.M., Selby Tulloch, W., Newsam, J.E. \& McLean, N. (1966) Chromosome studies on testicular cells from 50 subfertile men. Lancet ii, 69-71.

Means, A.R. (1974) Mechanisms of action of folliclestimulating hormone (FSH). In The Testis, vol. 4, pp. 163-188. Eds A. D. Johnsen \& W. R. Gomes. Academic Press, New York.

Mecklenburg, R.S., Hetzel, W.D., Gulyas, B.J. \& Lipsett, M.B. (1975) Regulation of FSH secretion: use of hydroxyurea to deplete germinal epithelium. Endocrinology 96, 564-570.

Millet, D., Plachot, M., Lety, M.A., de Grouchy, J. \& Netter, A. (1975) Les remaniements chromosomiques dans la stérilité masculine. J. Gynec. Obstet. Biol. Reprod. 4, 689-701.

Musto, N.A., Santen, R.J., Huckins, C. \& Bardin, C.W. (1978) Abnormalities of the pituitary-gonadal axis of $\mathrm{H}^{\text {re }}$ rats: a study of animals with an inherited disorder of seminiferous tubular and Leydig cell function. Biol. Reprod. 19, 797-806.

Rosen, S.W. \& Weintraub, B.D. (1971) Monotropic increase of serum FSH correlated with low sperm count in young men with idiopathic oligospermia and aspermia. $J$. clin. Endocr. Metab. 32, 410-416.

Searle, A.G. \& Beechey, C.V. (1974) Sperm count, egg fertilization and dominant lethality after $\mathrm{X}$ irradiation of mice. Mutat. Res. 22, 63-72.

Sheth, A.R., Dandekar, S.P. \& Seethalakshmi, N. (1981) Occurrence of bio-immuno active inhibin in rat spermatids. Andrologia 13, 232-235.

Steinberger, A. \& Steinberger, E. (1976) Secretion of an FSH-inhibiting factor by cultured Sertoli cells. Endocrinology 99, 918-921.

Thorneycroft, I.H., Ribeiro, W.O. \& Stone, S.C. (1973) A radio immunoassay of androstenedione. Steroids $\mathbf{2 1}$, 111-122.

Younglai, E.V. \& Chui, D.H.K. (1973) Testicular function in sterile Steel mice. Biol. Reprod. 9, 317-323.

Received 20 May 1982 